\title{
SEBARAN WAKTU REALISASI ANGGARAN BELANJA MODAL: STUDI FENOMENOLOGI PADA SEKRETARIAT DAERAH KABUPATEN GIANYAR
}

\author{
Anak Agung Ari Krisnawati ${ }^{1}$ \\ I Putu Sudana ${ }^{2}$ \\ Dewa Gede Wirama ${ }^{3}$ \\ ${ }^{1,2,3}$ Fakultas Ekonomi dan Bisnis Universitas Udayana, Bali, Indonesia \\ Email: gungari.krisnawati@gmail.com
}

\begin{abstract}
ABSTRAK
Fenomena yang melatari riset ini adalah waktu realisasi anggaran belanja modal pada Sekretariat Daerah Kabupaten Gianyar yang tidak proporsional. Realisasi anggaran tersebut cenderung mengalami peningkatan menjelang akhir tahun anggaran. Dengan metode fenomenologi transedental Husserl, penulis menggali makna dan esensi yang menjadi penyebab terjadinya fenomena. Pendekatan ini memiliki pandangan bahwa fenomena hanya dapat diamati melalui orang yang mengalami fenomena tersebut. Untuk dapat mengetahui penyebab terjadinya fenomena secara murni, peneliti menggali informasi dari beberapa informan yang memang memahami dan berkaitan langsung dengan fenomena. Informasi yang diperoleh kemudian didalami melalui proses epoche, hingga sampai pada inti dari fenomena. Dari proses epoche diketahui bahwa, menurut para informan, perencanaan anggaran merupakan faktor utama yang menyebabkan sebaran waktu realisasi anggaran belanja modal menjadi tidak proporsional dan cenderung terkonsentrasi di akhir tahun anggaran.
\end{abstract}

Kata kunci: Realisasi anggaran belanja modal, Fenomena, Perencanaan Anggaran.

\begin{abstract}
The phenomenon underliying of the research is realization of capital expenditure at the Regional Secretary of Gianyar Regency is disproportionately distributed due to the tendency of the realization that significantly increases toward the end of fiscal year. Using the method of transcendental phenomenology of Husserl, the researcher explores the meaning and essence that become the cause of the phenomenon. This approach states that the phenomenon can only be observed by those who experienced the phenomenon. In order to determine the cause of the phenomenon originally, the researcher seek information from numbers of informants who are directly related to the phenomenon.

The information obtained is then elaborated through epoche proces, until it reaches the core of the phenomenon. The result of epoche process is that budget planning is the main factor causing the temporal distribution at capital expenditure becomes disproportionate and tend to be concentrated at the end of fiscal year.
\end{abstract}

Keywords: Capital expenditure budgetes realization, phenomenon, Budget Planning. 


\section{PENDAHULUAN}

Peran penting anggaran dalam organisasi sektor publik berasal dari kegunaannya dalam menentukan estimasi pendapatan atau jumlah tagihan atas jasa yang diberikan (Tamasoleng, 2015). Anggaran itu sendiri merupakan teknik akuntansi yang dirancang untuk mengendalikan biaya melalui para pihak dalam organisasi (Argyris, 1953). Teori anggaran mengemukakan bahwa anggaran adalah rencana masa depan menyangkut mekanisme pengalokasian sumber daya serta alat penyaluran pendapatan (Wildavsky, 2004; Gayatri, 2014). Perkiraan pendapatan dan belanja memainkan peran penting dalam proses anggaran dan kebijakan pemerintah negara. Perkiraan ini umumnya dilaporkan eksekutif dan pemimpin legislatif sebagai titik perkiraan, dengan tidak ada pengakuan dari risiko dan ketidakpastian (Conia dan Nelson, 2004)

Belanja modal bagi negara yang sedang membangun, merupakan belanja yang sangat penting. Belanja modal digunakan untuk membangun infrastruktur seperti untuk pengadaan tanah, peralatan dan mesin, gedung dan bangunan, jalan dan jembatan, irigasi dan jaringan (Herriyanto, 2012). Semakin tinggi tingkat investasi modal diharapkan semakin mampu meningkatkan kualitas layanan publik, karena asset tetap yang dimiliki sebagai akibat adanya belanja modal merupakan persyaratan utama dalam memberikan pelayanan publik oleh pemerintah daerah (Darwanto dan Yustikasari, 2007). Alokasi anggaran belanja modal yang tinggi diharapkan mampu mengatasi kemiskinan apabila pelaksanaannya mencapai target yang dianggarkan (Ogujiuba, 2014). Di sisi belanja, pemerintah juga harus meramalkan pengeluaran untuk setiap program 
yang akan dilakukan secara rinci untuk masing-masing. Detail informasi yang disajikan tujuannya adalah untuk memungkinkan bagi legislatif untuk meninjau dan mengawasi pengeluaran pemerintah (Deng dan Peng, 2011).

Anggaran belanja yang realisasinya diusahakan mendekati 100\% menjelang akhir tahun anggaran, berdampak pada penumpukan jumlah realisasinya pada triwulan akhir tahun anggaran, terutama anggaran belanja modal (Muchsin dan Noor, 2011). Fenomena realisasi anggaran belanja modal yang cenderung terkonsentrasi menjelang akhir tahun anggaran berdampak pada keterlambatan masyarakat untuk menerima manfaat (Sukadi. 2012). Jika pelaksanaannya mundur ke akhir tahun padahal seharusnya bisa dilaksanakan lebih awal, maka pihak yang dirugikan sebenarnya adalah masyarakat banyak, karena tertunda menerima manfaat (Muchsin dan Noor. 2011). Kegagalan dalam mencapai target penyerapan anggaran memang berakibat hilangnya manfaat belanja, karena dana yang dialokasikan ternyata tidak semuanya dapat dimanfaatkan, yang artinya terjadi idle cash. Idle cash adalah dana yang berlebih di rekening kas pemerintah, yang belum terpakai untuk pembayaran kewajiban. Apabila idle cash sangat besar, hal ini bertentangan dengan prinsip-prinsip manajemen kas pemerintah yang baik (Herriyanto, 2012).

Williams (2004) menjelaskan bahwa secara garis besar tujuan manajemen kas pemerintah adalah untuk mampu membiayai pengeluaranpengeluaran pemerintah secara tepat waktu serta memenuhi kewajiban pemerintah ketika jatuh tempo, dengan mengaktifkan aktivitas biaya, pengurangan risiko dan efisiensi, serta menjaga saldo kas yang menganggur (idle cash) yang terdapat 
dalam sistem perbankan pada tingkat yang minimal. Keterbatasan sumber dana yang dimiliki negara dapat dioptimalkan untuk mendanai kegiatan strategis, apabila pengalokasian anggaran dilakukan dengan efisien. Sumber-sumber penerimaan negara yang terbatas mengharuskan pemerintah menyusun prioritas kegiatan dan pengalokasian anggaran yang efektif dan efisien. Ketika penyerapan anggaran gagal memenuhi target, berarti telah terjadi inefisiensi dan inefektivitas pengalokasian anggaran.

Fenomena menumpuknya realisasi anggaran menjelang akhir tahun anggaran terjadi pada Sekretariat Daerah Kabupaten Gianyar. Peningkatan realisasi anggaran yang cukup signifikan menjelang akhir tahun anggaran terjadi pada anggaran belanja modal, seperti terlihat pada Table 1.

Tabel 1.

Realisasi Belanja Modal Tahun 2013, 2014 dan 2015

\begin{tabular}{|c|c|c|c|c|c|c|c|c|c|}
\hline Tahun & $\begin{array}{c}\text { Rekenin } \\
\mathrm{g}\end{array}$ & Triwulan I & $\%$ & Triwulan II & $\%$ & Triwulan III & $\%$ & Triwulan IV & $\%$ \\
\hline 2013 & $\begin{array}{l}\text { Belanja } \\
\text { Modal }\end{array}$ & $\begin{array}{l}16.994 .750, \\
00\end{array}$ & 0,06 & $\begin{array}{l}7.220 .825 .750 \\
, 00\end{array}$ & 25,2 & $\begin{array}{l}4.106 .127 .700 \\
, 00\end{array}$ & 14,3 & $\begin{array}{l}17.334 .566 .45 \\
0,00\end{array}$ & 60,4 \\
\hline 2014 & $\begin{array}{l}\text { Belanja } \\
\text { Modal }\end{array}$ & $\begin{array}{l}4.700 .000,0 \\
0\end{array}$ & 0,0 & $\begin{array}{l}1.612 .519 .050 \\
, 00\end{array}$ & 8,0 & $\begin{array}{l}8.830 .826 .000 \\
, 00\end{array}$ & 43,6 & $\begin{array}{l}9.795 .706 .498 \\
, 00\end{array}$ & 48,4 \\
\hline 2015 & $\begin{array}{l}\text { Belanja } \\
\text { Modal }\end{array}$ & $\begin{array}{l}249.277 .000 \\
00\end{array}$ & 1,3 & $\begin{array}{l}5.575 .492 .000 \\
00\end{array}$ & 29,6 & $\begin{array}{l}3.067 .607 .550 \\
00\end{array}$ & 16,3 & $\begin{array}{l}9.967 .451 .900 \\
00\end{array}$ & 52,9 \\
\hline
\end{tabular}

Fenomena tersebut terjadi setiap tahun, sehingga diperlukan suatu kajian untuk mengetahui apa yang menyebabkan fenomena tersebut terjadi. Pihak yang paling mengetahui penyebab terjadinya fenomena adalah pihak-pihak yang memang terlibat langsung dengan fenomena. Mereka adalah informan yang bisa memberikan informasi tentang fenomena dari berbagai sudut pandang, dan mengetahui apa yang menjadi kendala senyatanya di lapangan. Untuk mencapai sasaran yang diinginkan maka pendekatan yang sesuai untuk digunakan dalam 
mengkaji fenomena tersebut adalah Fenomenologi Transedental Husserl. Fenomenologi Transedental Husserl membedakan pengalaman satu manusia dengan manusia lainnya, karena pengalaman setiap manusia akan membentuk persepsi, ingatan, ekspektasi, serta fantasi yang berbeda (Asih. 2005).

Pada studi fenomenologi informan yang baik adalah all individuals studied represent people who have experienced the phenomenon (Engkus. 2009). Informan dipilih karena dapat memberikan informasi yang relevan terhadap fenomena yang terdiri dari Kepala Sub Bagian (Kasubag) Analisa Kebutuhan dan Pengadaan pada Bagian Asset dan Perawatan (Asset dan Perwat), Pejabat Penatausahaan Teknis Kegiatan (PPTK) pada Bagian Pembangunan, Pejabat Penatausahaan Keuangan (PPK) Sekretariat, dan Pejabat Pengadaan sekaligus sebagai ketua Kelompok Kerja (Pokja) Unit Layanan Pengadaan (ULP).

Rumusan permasalahan dalam penelitian ini adalah bagaimana informan menginterpretasikan penyebab terjadinya fenomena realisasi anggaran belanja modal yang cenderung terkonsentrasi menjelang akhir tahun anggaran?

\section{METODE PENELITIAN}

Metode penelitian dapat diartikan sebagai cara ilmiah untuk mendapatkan data yang valid dengan tujuan dapat ditemukan, dikembangkan, dan dibuktikan, suatu pengetahuan tertentu sehingga dapat digunakan untuk memahami, memecahkan, dan mengantisipasi masalah (Sugiyono. 2009). Penelitian ini menggunakan pendekatan penelitian kualitatif, karena obyek penelitian ini adalah manusia. Penelitian kualitatif merupakan suatu prosedur penelitian yang menghasilkan data deskriptif berupa ucapan atau tulisan dan 
perilaku orang-orang yang diamati (Furchan. 1992). Penelitian ini menggunakan paradigma intepretif untuk memahami dan menjelaskan fenomena sebaran waktu realisasi anggaran belanja modal pada Sekretariat Daerah Kabupaten Gianyar yang cenderung terkonsentrasi menjelang akhir tahun anggaran.

Penelitian ini bermaksud untuk mengungkap esensi dibalik makna sebaran waktu realisasi anggaran belanja modal di Sekretariat Daerah Kabupaten Gianyar, yang cenderung terkonsentrasi menjelang akhir tahun anggaran. Fenomenologi Transedental Husserl ingin menemukan makna terdalam dari realitas kehidupan (Gill, 2014). Sesuai fenomenologi transedental, peneliti adalah orang yang mampu mentransformasikan data yang berasal dari informan menjadi gambaran yang murni dan utuh dari sebuah fenomena (Javier, 2012). Husserl mengemukakan epoche dalam fenomenologi transedental, dimana epoche merupakan sebuah metode penundaan asumsi terhadap realitas guna memunculkan hakekat (Hardiansyah. 2013, Smith and Mcintyre. 2004, Letiche. 2006). Dalam upaya memahami sebuah fenomena, seorang peneliti harus memiliki pemahaman yang cukup tentang objek yang akan ditelitinya (Sanders. 1982).

\section{HASIL DAN PEMBAHASAN}

\section{Interpretasi Informan A}

Informan A menganggap bahwa perencanaan anggaran adalah faktor kunci yang mempengaruhi terjadinya fenomena. Hal ini dapat di identifikasi dari epoche-epoche yang telah dirangkum dalam Gambar 1. 


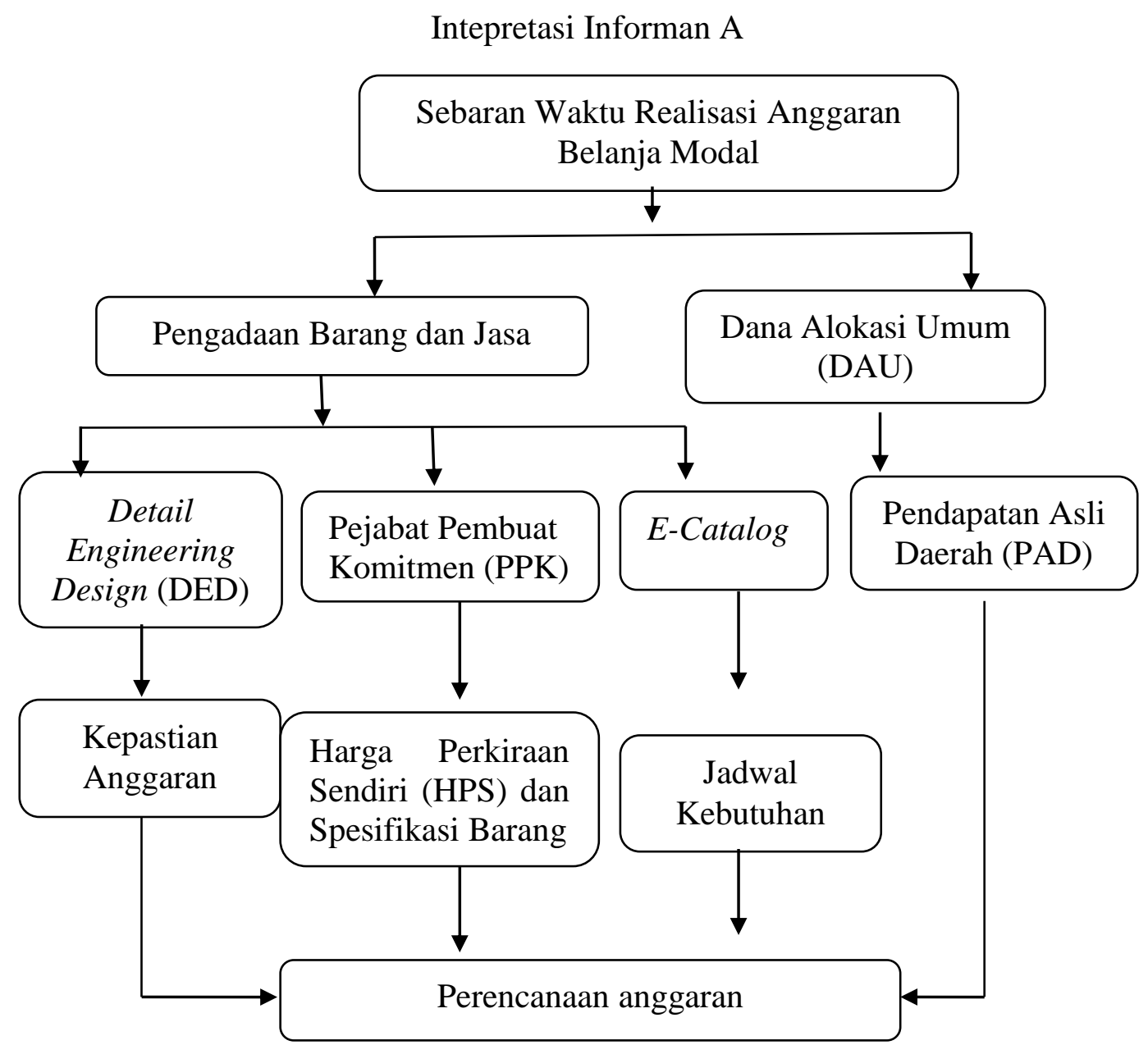

Gambar 1. Rangkuman interpretasi Informan A

Sebaran waktu realisasi anggaran belanja modal yang cenderung terkonsentrasi menjelang akhir tahun anggaran menurut intepretasi informan A disebabkan oleh pengadaan barang dan jasa dan Dana Alokasi Umum (DAU). Faktor penghambat dalam proses pengadaan barang dan jasa antara lain disebabkan oleh persiapan pelaksanaan teknis kegiatan pengadaan konstruksi atau Detail Engineering Design (DED) seperti apa yang di sampaikan informan berikut:

"Yang mempengaruhi juga adalah perencanaan teknis dalam tahun berjalan atau DEDnya (Ma-01A). Untuk pelaksanaan teknisnya, artinya 
membuat gambar disain kalau dia bangunan fisik, kalau gedung disain gedung seperti apa, kalau jalan juga pengerjaan jalan seperti apa (Ma-03)”.

DED dapat disiapkan sebelumnya, dengan catatan bahwa ada kepastian anggaran yang disiapkan untuk paket pengadaan tersebut. Kendalanya adalah apabila DED yang telah siap sebelumnya, tetapi pada saat APBD di sahkan tidak ada cukup dana untuk pengadaan tersebut sehingga tidak di anggarkan, maka hal ini akan menjadi temuan Badan Pemeriksa Keuangan (BPK). Hal itu terjadi karena untuk pembuatan DED itu sendiri membutuhkan biaya yang cukup besar, sehingga apabila paket kegiatan tersebut tidak dapat di danai APBD maka DED akan mubazir. Kondisi inilah yang menyebabkan DED tidak dapat dipersiapkan sebelumnya walaupun itu dapat mengatasi penumpukan realisasi anggaran belanja modal di akhir tahun anggaran.

Proses pengadaan barang dan jasa daerah, diadakan dengan EProcurement yang dilakukan melalui Unit Layanan Pengadaan (ULP). Keterlambatan pengadaan barang/jasa juga disebabkan karena keterlambatan penunjukan panitia/pejabat pengadaan barang dan jasa.

"Karena kan ketika ULP belum terbentuk, menunggu sampai terbentuknya ULP baru bias diproses pengadaannya(Ma-01A)".

ULP melaksanakan proses pengadaan apabila ada permintaan dari Pejabat Pembuat Komitmen (PPK), karena ULP hanya sebagai kendaraan untuk menemukan rekanan yang sesuai dengan spesifikasi yang diinginkan oleh PPK.

"Tergantung dari PPKnya, kan ULP cuma sebagai kendaraan untuk mendapatkan rekanan yang menyediakan barang (Ma-08).

Jadi pada prinsipnya, kelancaran dalam proses pengadaan bergantung pada kerjasama yang baik antara ULP dan PPK, serta kesigapan PPK dalam 
menentukan Harga Perkiraan Sendiri (HPS), spesifikasi teknis barang yang diinginkan, dan pengambilan keputusan penentuan rekanan yang telah dipersiapkan oleh ULP.

Kesigapan PPK dalam memproses pengadaan yang telah disiapkan oleh ULP menjadi indikator penting mempercepat proses pengadaan. Kendala yang dihadapi PPK dalam proses pengadaan adalah penentuan Harga Perkiraan Sendiri (HPS) dan penentuan spesifikasi barang.

"PPK kendalanya di penentuan harga untuk pembuatan HPS. Menentukan HPS saja lama, kan otomatis mulai kerjanya lama, belum lagi penentuan spesifikasi barangnya lama, bisa-bisa pertengahan baru proses pengadaan. Pembayarannya kan pasti akhir tahun (Ma-08A)".

Penerbitan E-Catalog dijadikan dasar untuk memulai kegiatan pengadaan barang modal, apakah barang yang akan diadakan tercantum dalam E-Catalog atau tidak, akan menentukan mekanisme pengadaannya. Keterlambatan launching ECatalog, dapat menunda proses pengadaan barang modal yang sedianya dapat dilakukan pada semester awal tahun anggaran seperti yang disampaikan informan dalam petikan wawancara berikut:

"Kalau barang nike [itu] kan biasanya kalau dia E-procument atau ECatalog, kesiapan E-Catalog sudah tercantum ten [tidak], biasanya kita memanginginnya kita cepat, tetapi E-Catalog tidak ada, kita kan masih menunggu launching di muatnya E-Catalog (Ma-05A)".

Apabila dalam perencanaan anggaran telah ditentukan jadwal kebutuhannya, triwulan keberapa pengadaan akan dilakukan, maka persiapan dapat dilakukan sambil menunggu penerbitan E-Catalog seperti yang disampaikan informan dalam petikan wawancara berikut:

"Perencanaan itu yang penting, apa barang itu dibutuhkan di awal tahun atau di triwulan ketiga, keempat kebutuhan untuk barang tersebut. Kalau 
memang oprasional membutuhkan segera, bisa triwulan pertama diadakan, kembali lagi pada E-Catalog, kalau barang sudah siap lebih cepat bisa (Ma-05A).

Faktor lain sebagai penyebab terjadinya konsentrasi realisasi anggaran belanja modal menjelang akhir tahun anggaran yaitu pemotongan dana transfer pusat ke daerah. Pola perencanaan pada Sekretariat Daerah Kabupaten Gianyar belum mampu memprediksi dan mengatasi kemungkinan adanya pemotongan dana tersebut sehingga banyak kegiatan yang harus di pangkas seperti yang disampaikan oleh informan:

"Ada pemotongan dari pusat, itu berarti ada kegiatan yang harus dipangkas (Ma-06A)".

Apabila ada kemungkinan mendapatkan dana saat anggaran perubahan, maka tender dapat dilakukan setelah anggaran perubahan, sehingga otomatis pelaksanaannya menjelang akhir tahun anggara. Perencanaan anggaran adalah faktor yang mempunyai pengaruh paling awal dalam proses realisasi anggaran seperti yang diungkapkan informan berikut:

"Biasanya kan awal dari anggaran itu adalah penyusunan anggaran, paling yang berperan nike [itu] dari perencanaan anggaran, karena semua yang akan dilakukan selanjutnya basisnya dari perencanaan. Penempatan kegiatan belanja modal triwulan keberapa itu sangat berperan di depan. Itu yang menjadi persoalan disini, perencanaannya belum memadai (Ma01A)".

Pengadaan yang memang bisa dilakukan di awal tahun anggaran dapat dilaksanakan di awal sesuai dengan kebutuhan, sehingga semua pengadaan tidak harus terkonsentrasi di akhir tahun anggaran, walaupun ada pengadaan yang realisasinya harus di akhir tahun. 


\section{Intepretasi Informan B atas fenomena}

Intepretasi informan B seperti rangkuman dalam Gambar 2.

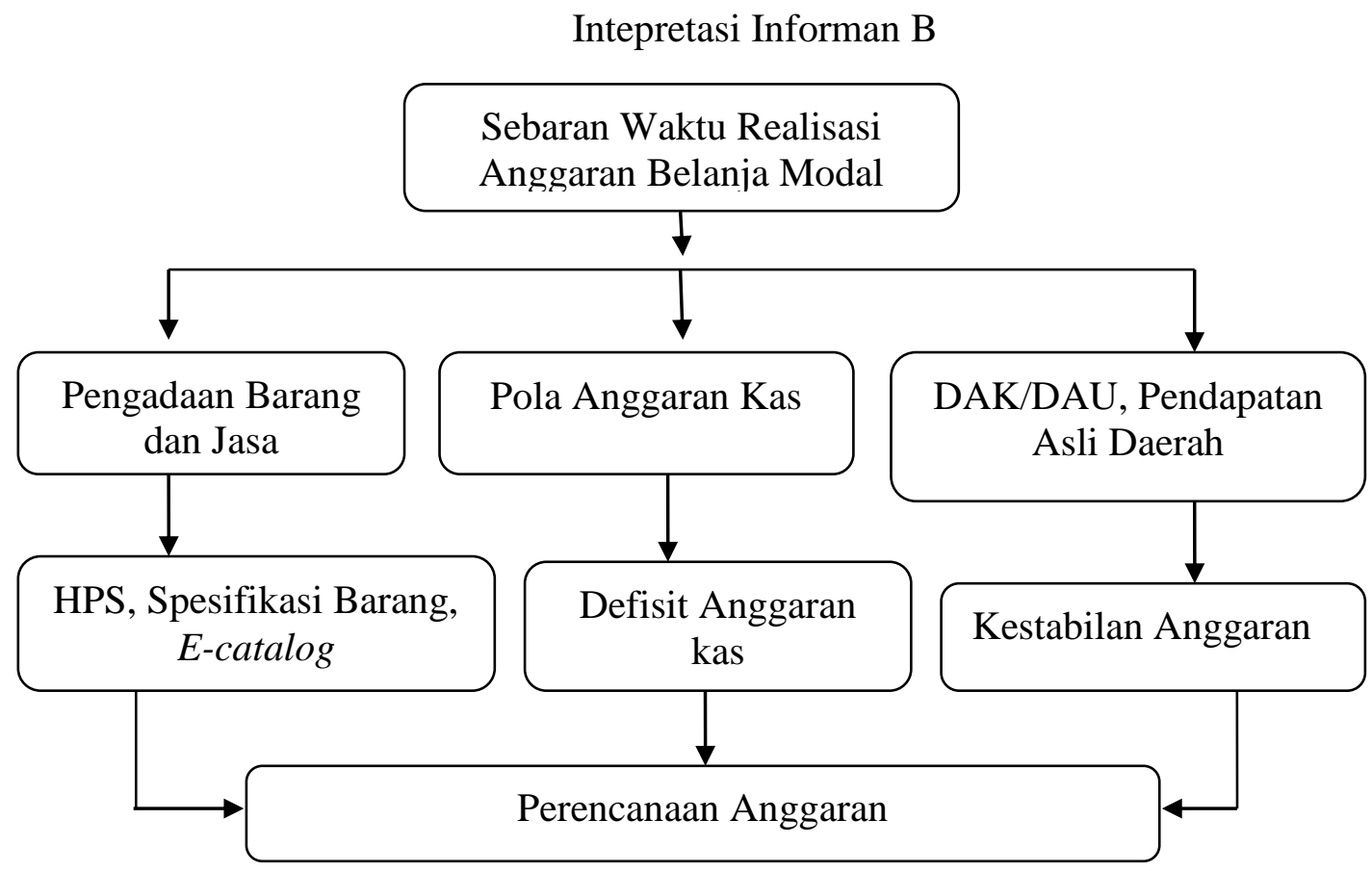

Gambar 2. Rangkuman interpretasi Informan B

Sebaran waktu realisasi anggaran belanja modal yang cenderung terkonsentrasi menjelang akhir tahun menurut informan B dipengaruhi oleh pendapatan. Pendapatan daerah yang mempengaruhi realisasi belanja modal yaitu pendapatan yang bersumber dari Pendapatan Asli Daerah (PAD) dan Dana Transfer Pusat untuk daerah (DAK/DAU). Menurut informan besarnya jumlah PAD dalam APBD merupakan sebuah asumsi, asumsi bahwa daerah akan menghasilkan pendapatan sebesar yang di anggarkan seperti yang disampaikan informan berikut:

"Pendapatan kan juga berdasarkan asumsi, apakah kita mendapatkan sekian, tapi kalau gak sampai kan masalah (Ma-08B)". 
Perolehan PAD yang belum pasti berdampak pada pola perencanaan belanja modal yang menyesuaikan dengan pendapatan daerah pada tahun berjalan. Untuk menjaga kestabilan anggaran, maka anggaran belanja modal sengaja ditempatkan pada triwulan akhir tahun anggaran, menunggu kepastian pendapatan yang akan dialokasikan untuk belanja modal.

"Kalau belanja modal, kalau dulu kan menjaga kestabilan anggaran, anggaran itu dijaga biar tidak minus, menjaga kalau ada pemotongan atau ada apa, untuk kestabilan, sehingga belanja modal itu di usahakan direalisasikan akhir tahun (Ma-03B)".

Belanja modal tergantung pada perolehan PAD saat tahun berjalan, karena apabila pencapaian pendapatan tidak sesuai dengan target yang dianggarkan, maka akan terjadi defisit anggaran, sehingga mengurangi belanja modal. Apabila pendapatan melampaui target yang ditetapkan, maka merencanakan belanja modal, seperti yang disampaikan informan B dalam petikan wawancara berikut:

"Kalau dia melebihi target pendapatannya, menggangarkan belanja modal. Kalau defisit, mengurangi dia belanja modal (Ma-11B)".

Penempatan perencanaan belanja modal di akhir tahun anggaran juga dimaksudkan untuk menghindari dominasi belanja modal dalam APBD. Menurut pendapat informan, apabila belanja modal direncanakan sebelum ada kepastian pendapatan telah mencapai target yang dianggarkan, dikhawatirkan nantinya belanja modal menghabiskan terlalu banyak anggaran, sehingga kegiatan rutin lainnya kekurangan anggaran.

"Iya, karena kan untuk mengantisipasi defisit anggaran, pendapatan dengan belanja kan gak balance dia, nanti kalau pendapatannya semua habis untuk belanja modal kan masalah itu (Ma-07B)". 
Kondisi tersebut mengakibatkan banyak kegiatan belanja modal yang tidak melalui perencanaan anggaran. Belanja modal banyak yang mendapatkan anggaran saat anggaran perubahan, karena pola perencanaannya memang dibuat sedemikian rupa untuk menjaga kestabilan anggaran.

Penetapan angka pendapatan dalam APBD juga tergantung pada informasi dana transfer dari pusat. Besaran alokasi dana transfer pusat untuk daerah setiap tahunnya tidak ada kepastian. Karena ketidakpastian akan besaran dana transfer pusat untuk daerah, maka pemerintah daerah cenderung berhati-hati dalam mengganggarkan belanja modal agar tidak terjadi defisit anggaran belanja, seperti yang disampaikan informan berikut:

"Kayak sekarang saja sudah masalah, DAU DAK sudah kita melaksanakan kontrak, tau tau DAU DAK dipotong sama pusat (Ma08B)".

Pemotongan Dana Alokasi Umum (DAU) dan Dana Alokasi Khusus (DAK) berdampak pada pengurangan pada anggaran belanja modal. Pengadaan yang sudah di rencanakan di geser pelaksanaannya menunggu dana perubahan.

"Padahal sudah tanda tangan kontrak bisa batal atau bisa pengurangan kontrak (Ma-08B). Di perubahan itu di geser, atau ditiadakan kalau memang dananya tidak ada (Ma-13B)".

Apabila pada anggaran perubahan tidak terdapat anggaran yang mencukupi, maka pengadaan yang walaupun sudah penandatanganan kontrak bisa dibatalkan. Pengadaan yang murni di danai oleh Pendapatan Asli Daerah (PAD), pelaksanaannya masih bisa dilaksanakan walaupun anggaran tidak mencukupi (defisit anggaran belanja), dimana pendanaanya berasal dari cadangan modal seperti yang diungkapkan informan berikut: 
"Tapi kalau anggarannya bukan dari pusat, masih bisa dipaksakan, tapi defisit jadinya kalau pendapatan daerah tidak memenuhi target, nanti cadangan modal yang ditarik (Ma-13B)".

Pola anggaran kas juga berpotensi menjadi penyebab penumpukan realisasi anggaran. Seringkali penyerapan anggaran pertriwulannya tidak mencapai target, sehingga anggarannya bertumpuk di saldo rekening kas daerah

"Itu dah kesalahan dia menganggarkan sebenarnya, dipasang di triwulan pertama semua anggaran kasnya (Ma-14B)".

Pengamprahan anggaran kas memang sengaja dilakukan pada triwulan pertama tahun anggaran, untuk menghindari kekurangan kas saat proses belanja.

"Itu dah kesalahan dia menganggarkan sebenarnya, dipasang di triwulan pertama semua anggaran kasnya, karena diharapkan kalau dana sudah ada kan bisa di amprah sedikit-sedikit, biar gak habis anggaran kasnya, kalau sedikit di amprah, takutnya kurang dananya malah gak bisa amprah. Makanya di amprah sekalian di awal biar tenang. Walaupun anggaran masih sisa di triwulan pertama, triwulan kedua amprah lagi sehingga numpuk dia, itulah akibat dari kesalahan perencanaan. (Ma-14B)".

Menjadi persoalan apabila ada pemeriksaan dilakukan oleh pusat, dan ditemukan terjadinya penumpukan saldo Dana Alokasi Umum (DAU) dan Dana Alokasi Khusus (DAK) pada rekening kas daerah, maka untuk periode berikutnya anggaran DAU dan DAK akan di potong, menyesuaikan dengan kemampuan daerah untuk merealisasikannya.

"Kalau DAU dan DAK ditumpuk, nanti di cek sama pusat ternyata dana masih banyak menumpuk, anggaran tahun beruikutnya bisa dipotong" (Ma-14B).

Pola perencanaan anggaran yang kurang baik berimbas pada pola anggaran kas, sebagai akibat tidak adanya kepastian akan belanja yang akan dilakukan per triwulannya, sehingga menimbulkan ketakutan akan kekurangan kas untuk belanja yang mendadak. 
Hambatan dalam pengadaan barang/jasa yang memicu penumpukan realisasi anggaran yaitu terlambatnya proses pelaksanaan pengadaan, sehingga proses amprah pembayarannya mundur ke akhir tahun anggaran. Salah satu penyebab keterlambatan proses pengadaan adalah, kesiapan E-katalog.

"Kita kan pakai E-catalog, E-catalog gak muncul-muncul, april baru muncul, kan susah (Ma-16B)".

Penerbitan E-catalog biasanya dilakukan pada bulan april tahun anggaran, sehingga pengadaan baru dapat dilakukan pada bulan juni, setelah kesiapan dokumen pengadaan selesai. Hambatan lain dalam proses pengadaan disebabkan oleh penentuan tipe spesifikasi barang. Banyaknya usulan dan keinginan dari atasan menyebabkan kesulitan dalam memutuskan tipe yang harus dibeli, sehingga waktu yang dibutuhkan juga lama.

"Ada yang mengusulkan tipe ini, ada yang usul tipe itu, menentukan tipe barang saja sudah banyak menghabiskan waktu (Ma-17B)”.

Perencanaan anggaran yang kurang memadai menjadi faktor inti yang mempengaruhi realisasi anggaran. Perencanaan belanja modal yang sengaja ditempatkan saat anggaran perubahan serta hambatan yang dialami dalam proses pengadaan merupakan akibatkan dari perencanaan anggaran yang kurang memadai dan tidak melalui mekanisme perencanaan yang baik seperti yang tersirat dalam pernyataan informan berikut:

"Penyusunan anggaran dari Renja, Renstra, RKA, menjadi DPA juga harus baik, sehingga penumpukan realisasi itu gak terjadi. Itu masalah dan kondisi pengelola keuangan yang masih belum baik. Jadi semua terkait perencanaan (Ma-17B)". 


\section{Intepretasi Informan C atas Fenomena}

Proses epoche yang dilakukan pada data informan $\mathrm{C}$, dapat disimpulkan bahwa perencanaan anggaran merupakan penyebab inti terjadinya konsentrasi realisasi anggaran pada Sekretariat Daerah Kabupaten Gianyar. Hal tersebut tercermin dari pernyataan informan yang telah dirangkum dalam Gambar 3.

Intepretasi Informan C

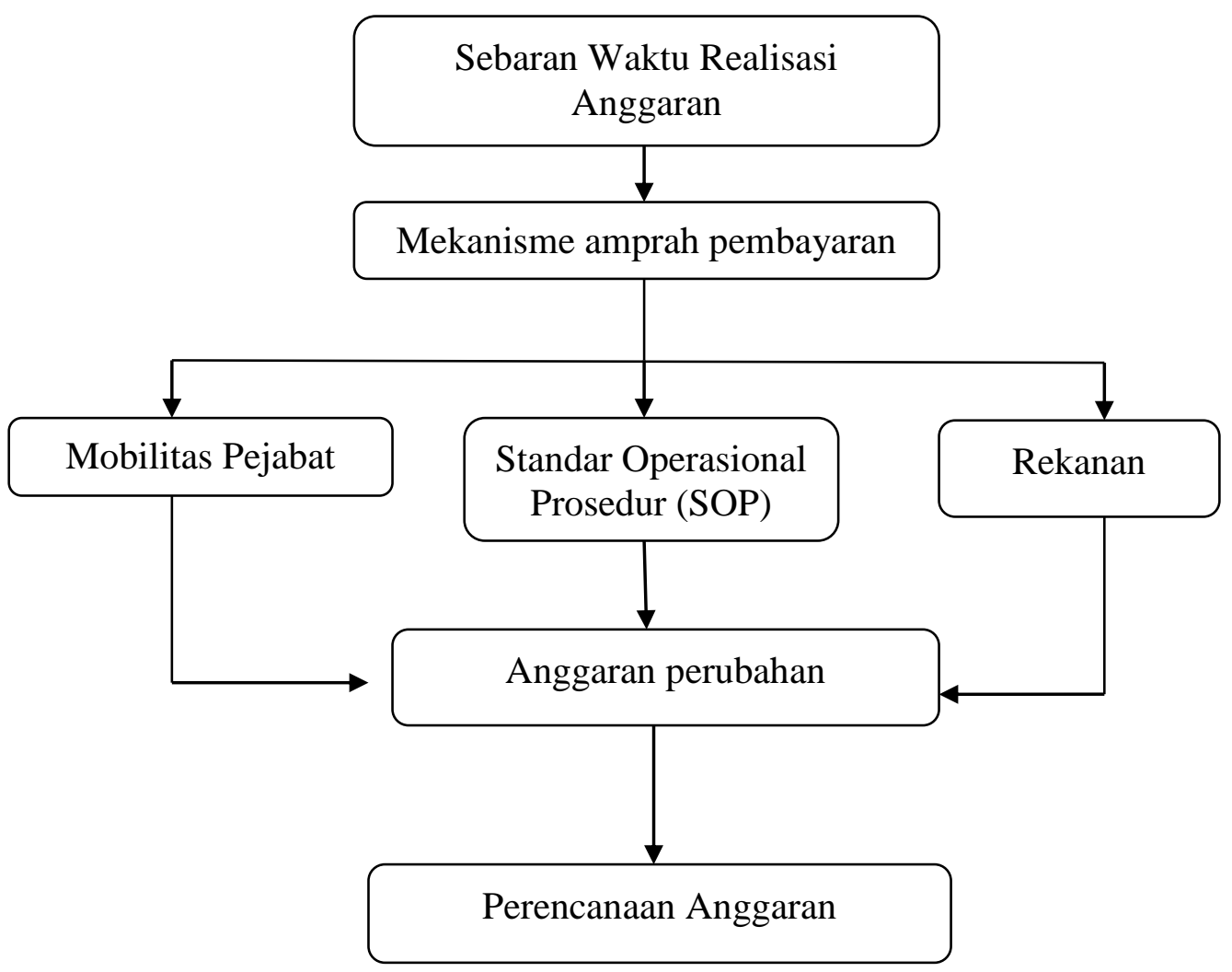

Gambar 3. Rangkuman interpretasi Informan C

Mekanisme dalam proses pembayaran belanja modal, dapat menghambat proses realisasi anggaran sehingga seringkali terkonsentrasi di akhir tahun anggaran. Hal tersebut terjadi karena banyak kendala yang dialami saat proses persiapan dokumen pembayaran. Perbaikan yang dilakukan membutuhkan waktu 
lama, karena harus mencari otorisasi ulang baik dari rekanan maupun pejabat terkait untuk kelengkapan dokumen amprah seperti yang disampaikan oleh informan berikut:

"Orang amprahnya salah kan otomatis dikembalikan, kalau disini sehari saja sudah selesai periksa, tapi kalau dikembalikan untuk diperbaiki itu yang kembalinya lama. Dia perbaiki, nyari tanda tangan lagi, tanda tangan pejabat, rekanan, itu dah yang lama. Kalau sudah sekali benar kan gak perlu ngulang. Kadang dari proses SPP ke SPM juga lama, kadang bisa dua minggu. (Ma-06C).

Apalagi mobilitas dari pejabat-pejabat yang tinggi dapat memperburuk keadaan, karena memerlukan waktu yang lama untuk mencari tanda tangan para pejabat terkait. Tahun 2015 menurut informan, mobilitas para pejabat sangat tinggi untuk perjalanan dinas, mengakibatkan persiapan dan perbaikan dokumen amprah terhambat.

"Tahun lalu mobilitas pejabat juga tinggi, banyak pejabat yang keluar daerah, perjalanan dinas. Terbang aja terus gimana mau tanda tangan pejabatnya, kan lama jadinya (Ma-06C).

Kesesuaian dokumen pembayaran dengan Standar Operasional Prosedur (SOP) yang ditetapkan juga mempengaruhi realisasi anggaran. Banyak dokumen pembayaran yang harus di revisi karena tidak sesuai dengan SOP. Namun SOP juga menjadi penghambat dalam proses realisasi anggaran, karena SOP mengenai kelengkapan dokumen pembayaran terlalu sering mengalami perubahan yang menyebabkan kebingungan dalam mempersiapkan dokumennya.

"Kadang banyak amprah yang ditolak karena kelengkapannya tidak sesuai SOP. SOP juga sering berubah, menyesuaikan dengan temuan BPK biasanya. Jani [sekarang] amprah dibawah 10 juta perlu kwitansi dan nota saja, minggu depannya bisa berubah lagi, mungkin perlu di tambahkan surat pesanan atau surat serah terima barang. Sudah kembali amprahnya, nyiapin itu dulu, udah lama lagi baliknya, kan otomatis pencairan dananya lama jadinya (Ma-06C). 
Dibutuhkan banyak waktu untuk merevisi kesalahan dokumen pembayaran, yang berimbas pada terhambatnya proses pencairan dana.

Terhambatnya mekanisme amprah pembayaran juga disebabkan oleh rekanan penyedia barang modal, dikarenakan keengganan mereka melakukan amprah pembayaran uang muka pekerjaan. Seperti yang disampaikan oleh ibu parlina berikut, bahwa rekanan sering terlambat dalam menyampaikan dokumen amprah pembayaran.

"Rekanan juga jadi pemicu, karena banyak rekanan yang punya proyek dimana-mana, dia mengutamakan proyek yang lebih besar. Walaupun pekerjaan sudah selesai, tapi belum amprah juga, itu sudah biasa (Ma01C).

Kalau kwitansi barang dan nota gak datang-datang dari rekanan, gimana mau amprah ? (Ma-02C)"

Mereka cenderung memproses dokumen pembayaran saat proyek telah selesai dikerjakan, tanpa di awali amprah uang muka.

Pada prinsipnya semua kendala yang dihadapi dalam proses realisasi anggaran belanja modal sebagai akibat dari perencanaan anggaran yang kurang memadai. Banyak anggaran yang justru diperoleh saat anggaran perubahan, sementara pagu anggaran induk yang tertuang dalam RKA, mengadopsi anggaran tahun lalu seperti yang disampaikan informan berikut ini:

"Perencanaan juga mempengaruhi, banyak anggaran yang di dapat saat anggaran perubahan. Anggaran induk biasanya sama dengan anggaran tahun lalu"

Kondisi tersebut mengakibatkan banyak kegiatan yang realisasinya baru bisa dilakukan pada triwulan ke empat. Anggaran perubahan baru dapat direalisasikan pada bulan oktober sehingga banyak kegiatan yang pengerjaannya dipercepat dan 
mengesampingkan kelengkapan dokumen pembayaran seperti yang disampaikan informan $\mathrm{C}$ :

"Iya pasti, jadinya kan kejar kejaran, Cuma 3 bulan lho waktunya itu. Akhirnya amprahnya asal-asalan dulu, yang penting bisa keluar uangnya, kelengkapan amprahnya nyusul, begitu kejadiannya yang sering disini" (Ma-04C).

Dalam proses perencanaan anggaran daerah, permasalahan yang sering dihadapi adalah adanya perbedaan program-program prioritas antara pihak eksekutif dan DPRD. Sebenarnya masing-masing bagian sudah melakukan perencanaan penganggaran dengan baik, namun pada akhirnya setelah beberapa kali sidang TAPD, rencana tersebut tidak mendapatkan persetujuan dan kembali pada format anggaran tahun sebelumnya, sebagaimana penuturan dari Ibu Parlina sebagai berikut:

"Sebenarnya sudah membuat perencanaan yang bagus, tapi setelah berapa kali sidang TAPD, pada akhirnya kembali ke pagu induk, selalu seperti itu, itu kayaknya penyebab utama kayaknya (Ma-03C)"

Banyak kegiatan belanja modal yang anggarannya diperoleh saat anggaran perubahan, sehingga tidak ada perencanaan yang baik akan belanja modal pada awal tahun anggaran, yang dapat dijadikan pedoman dalam pelaksanaan belanjanya.

\section{Intepretasi Informan D}

Proses epoche atas pernyataan dari informan $\mathrm{D}$, menyimpulkan bahwa perencanaan anggaran menjadi penyebab terjadinya penumpukan realisasi anggaran belanja modal seperti yang terangkum dalam Gambar 4. 
Intepretasi Informan D

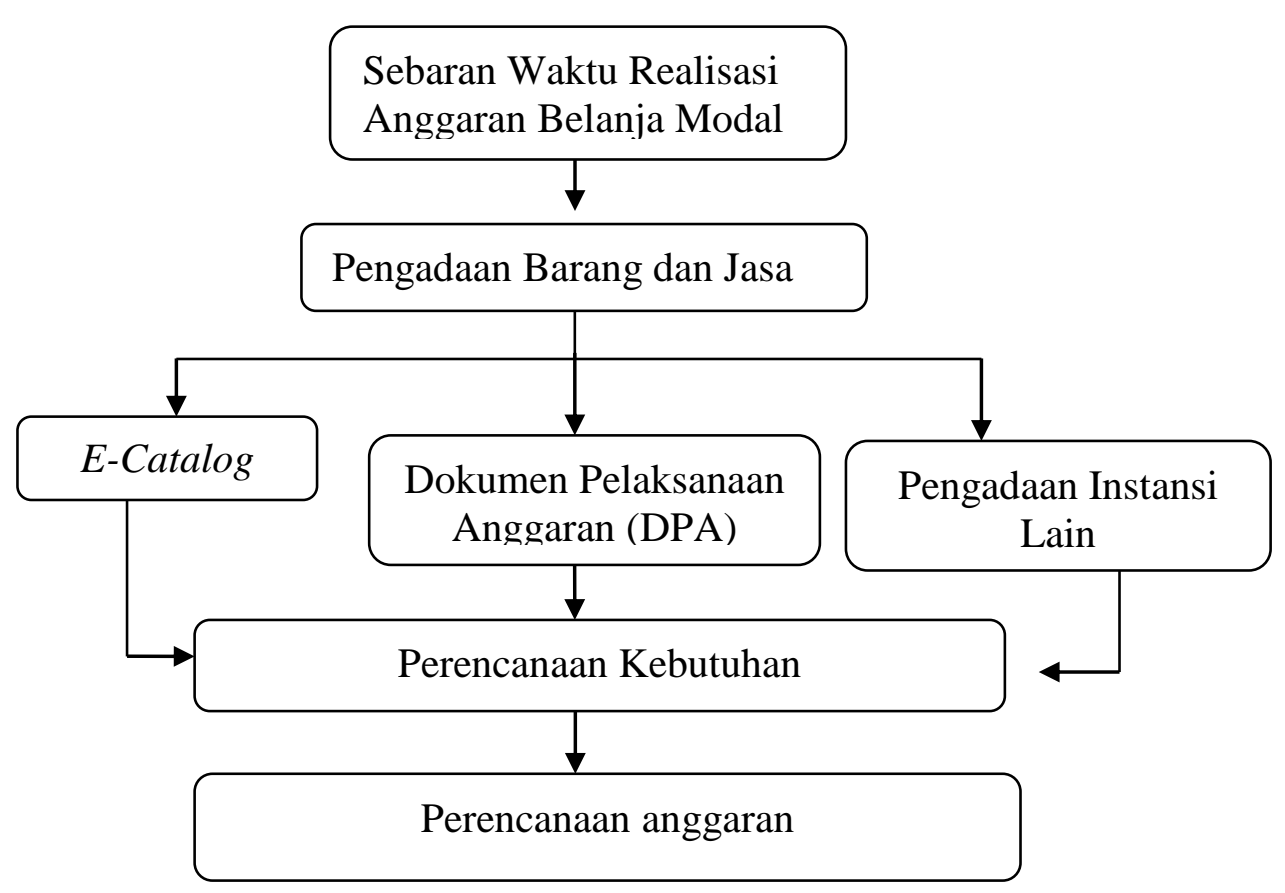

Gambar 4. Rangkuman interpretasi Informan D

Proses Pengadaan barang dan jasa menjadi penyebab terjadinya penumpukan realisasi anggaran belanja modal menjelang akhir tahun anggaran. Keterlambatan penerbitan E-catalog dari pusat menyebabkan pelaksanaan belanja modal menjadi tertunda, menunggu terbitnya E-catalog. Pelaksanaan pengadaan barang modal akan semakin terlambat manakala setelah penerbitan E-catalog oleh pusat, ternyata barang-barang yang direncanakan pengadaannya tidak tertera dalam E-catalog seperti yang dituturkan oleh informan berikut:

April baru ada E-catalog, kadang barang yang di cari malah sing ade [tidak ada] di E-catalog, itu yang bikin lama (Ma-02D).

Selain keterlambatan penerbitan E-catalog oleh pusat, kendala lain yang di hadapi panitia pengadaan barang modal adalah, adanya kenaikan harga barang pada $E$ catalog, sehingga dana yang dianggarkan pada RKA tidak mencukupi. 
"Pernah kejadian tahun lalu, mau pengadaan mobil, ternyata dana yang di anggarkan kurang, harga di E-catalog lebih mahal karena ada kenaikan harga, akhirnya gak bisa pengadaan, nunggu lagi pas anggaran perubahan (Ma-05D)".

Hambatan dalam proses pengadaan barang/jasa juga disebabkan oleh keterlambatan penerimaan DPA pada masing-masing bagian.

"Kadang-kadang awal tahun tu kita gak dapat DPA" (Ma-02D).

"Itu dah susahnya gung, dije kaden nyangklek [dimana dia tertinggal]" (Ma-03D).

Penumpukan realisasi anggaran di akhir tahun juga dipicu oleh pengadaan barang modal dari dinas lain di luar Sekretariat Daerah yang tidak memiliki anggaran di dinas masing-masing, sehingga pengadaannya di lakukan pada bagian Asset dan Perwat. Hal tersebut mengakibatkan tidak tersedianya cukup dana yang berimbas pada kegiatan yang sudah direncanakan sehingga pelaksanaannya diundur menunggu dana perubahan.

"Dini di perwat sai san maan pengadaan dadakan [disini di Perwat sering mendapatkan pengadaan dadakan], kadang di bagian lain atau dinas lain ade pengadaan, tapi sing ngelah [tidak punya] dana, mai be ke perwat tumpel $e$ [di perwat diadakan], dini kuang be dana $e$ [disini kekurangan dana], makane dini dadi [makanya disini jadi] obyek penampungan. Waktu ini lucu bin [Waktu ini lucu], sampai mines pagu ne [pagunya], terpaksa diakui hutang to [itu], nganggeh [ngutang] ajak pihak ketiga (Ma-10D)".

Proyek pengadaan dari dinas atau bagian lain yang pada dasarnya tidak dianggarkan di bagian asset dan perwat, memicu penumpukan realisasi anggaran belanja modal di triwulan akhir tahun anggaran, karena secara otomatis menunggu dana dari anggaran perubahan. Semua kendala yang terjadi berkaitan dengan proses pengadaan barang/jasa diakibatkan oleh perencanaan kebutuhan akan 
barang modal pada Sekretariat Daerah Kabupaten Gianyar kurang memadai, seperti yang disampaikan informan berikut:

"Di perencanaan kebutuhannya gung. Padahal kan kita harusnya sudah tau apa yang mau dibeli atau di adakan, akhirne [akhirnya] sing [tidak] direncanakan, nah [ya] kayang ne [nanti] di anggaran perubahan je [saja] anggarkan, keto [begitu]. Itu dah kelemahannya kita, memprediksi kebutuhan to [itu] sing [tidak] bise [bisa], kadang kadang jeg tiba-tiba pengadaan pas anggaran perubahan mare [baru] di anggarkan, liu [banyak] muncul pengadaan baru. Itu kelemahan bos-bos [atasan] rage [kita] $e$, sing [tidak] ngidang [bisa] memprediksi apa yang dibutuhkan (Ma-08D)".

Banyak pengadaan barang modal yang tidak dianggarkan pada anggaran induk, melainkan dianggarkan pada saat anggaran perubahan. Kelemahan dalam proses perencanaan kebutuhan pada anggaran induk, menyebabkan banyak kegiatan yang muncul pada saat anggaran perubahan

Perencanaan dan penganggaran merupakan proses yang terintegrasi, dimana output dari perencanaan adalah penganggaran. Perencanaan anggaran dilakukan tanpa mekanisme mempersiapkan Rencana Kerja (Renja) atau Rencana Strategi (Renstra) seperti yang disampaikan oleh informan berikut:

"Ah nak ngawag ngae Renja Renstra to. Kadang be ditetapkan bise dirubah, bin masukin kegiatan baru di perubahan (Ma-09D)".

[Ah asal itu dalam pembuatan rencana kerja (RENJA) dan rencana strategis (RENSTRA). Kadang sudah ditetapkan bisa di rubah, lagi memasukkan kegiatan baru di perubahan].

Apa yang dibutuhkan, program yang akan dilaksanakan dan ketersediaan anggaran akan tertuang dalam perencanaan anggaran daerah, sehingga proses perencanaan anggaran sebagai pijakan dalam pelaksanaan anggaran. Perencanaan kebutuhan yang baik seharusnya jelas memuat akan apa yang dibutuhkan, tujuan pengadaannya dan Kerangka Acuan Kerja (KAK), tetapi pada kenyataannya hal 
tersebut tidak di laksanakan. Hal tersebut disampaikan informan dalam penuturannya berikut:

"Iya harusnya gitu, itu yang bagus sebenarnya, sudah ada KAK ne. Tapi kenyataane sing ade keto [tidak seperti itu] (Ma-05D)".

Dampak dari pemahaman yang kurang baik dari tim perencana anggaran, akan menghasilkan program-program yang tidak sesuai dengan apa yang dibutuhkan sehingga banyak kegiatan yang baru dapat direalisasikan saat anggaran perubahan. Semua hambatan dalam proses pengadaan barang dan jasa bersumber dari pola perencanaan anggaran yang kurang memadai.

\section{Esensi Pemahaman Informan}

Perencanaan merupakan suatu proses berkesinambungan yang mencakup keputusan atas berbagai alternatif penggunaan sumber daya untuk mencapai tujuan tertentu pada masa yang akan datang (Conyers, Hills. 1984). Permasalahan rendahnya penyerapan anggaran di awal tahun anggaran disebabkan oleh lemahnya sistem perencanaan anggaran. Instansi kurang siap dalam menyusun rencana anggaran, yang berdampak pada kualitas dokumen anggaran (DPA) dan pelaksanaan anggarannya memerlukan waktu untuk melakukan penyesuaian, termasuk revisi DPA (Siwanto dan Rahayu, 2010).

Realisasi anggaran belanja modal dipengaruhi oleh bagaimana pola perencanaan dan penganggaran di daerah. Perencanaan anggaran yang kurang matang akan berpengaruh terhadap proses realisasi program yang ditetapkan (Arif dan Halim. 2011). Pola perencanaan yang kurang memadai akan menyulitkan dalam realisasinya, karena tidak ada pedoman pasti tentang apa yang dibutuhkan, kapan pelaksanaannya, berapa lama waktu yang dibutuhkan, dan berapa anggaran 
yang disediakan. Informan D mengindikasikan bahwa, penganggaran tahun berikutnya hanya berdasarkan pada anggaran tahun lalu, sehingga banyak menghasilkan program-program yang tidak sesuai dengan apa yang dibutuhkan. Idealnya kegiatan yang direncanakan merupakan kegiatan yang benar-benar dibutuhkan, baik jenis maupun jumlah dalam rangka memenuhi tugas pokok dan fungsi organisasi. Rencana kebutuhan diformulasikan dari barang-barang apa saja yang dibutuhkan untuk mendukung pelaksanaan tugas dan fungsi Kementerian/Lembaga/Daerah/Instansi dikurangi dengan barang-barang apa saja yang saat itu telah tersedia dan siap digunakan (Miliasih, 2012).

Untuk menjaga kestabilan anggaran maka penetapan pagu anggaran belanja modal di akhir tahun anggaran sebagai langkah untuk mengantisipasi kekurangan anggaran daerah. Langkah tersebut di ambil sebagai akibat tidak ada perencanaan yang pasti akan pendapatan yang diperoleh daerah dan belanja modal yang akan dilakukan. Apabila pendapatan daerah telah mencapai target, maka menganggarkan belanja modal. Tetapi apabila anggaran pendapatan tidak mencapai target yang di anggarkan, maka akan mengurangi belanja modal. Kemampuan masing-masing kepala bagian selaku Pejabat Pelaksana Teknis Kegiatan (PPTK) yang terlibat dalam proses perencanaan dan penganggaran sangat penting. Mereka dituntut mampu membuat perencanaan yang selaras antara perencanaan yang ditetapkan dengan program kerja yang akan dilaksanakan.

Kesalahan dalam pengelolaan Uang Persediaan (UP) menjadi salah satu faktor yang menyebabkan anggaran kas daerah seolah-olah penyerapannya rendah. Ini diakibatkan oleh kekhawatiran penyelenggara kegiatan akan 
kekurangan kas pada pertengahan kegiatan, karena tidak bisa amprah kas lagi pada triwulan yang sama. Menjelang akhir tahun anggaran mereka berlomba untuk merealisasikan anggaran kas yang masih banyak tersisa, sehingga realisasinya menjadi terkonsentrasi di akhir tahun. Kondisi tersebut terjadi karena perencanaan kebutuhan belanja modal kurang memadai, sehingga menimbulkan ketakutan akan kekurangan anggaran kas saat terjadi realisasi belanja.

Perubahan SOP akan kelengkapan dokumen amprah pembayaran sangat sering terjadi, padahal kondisi tersebut dapat menghambat proses pembayaran dikarenakan pengulangan persiapan dokumen. Kepastian SOP mengenai kelengkapan dokumen pembayaran dapat meminimalisasi kesalahan dalam proses persiapan dokumen pembayaran, sehingga proses pembayaran tidak perlu mengalami perbaikan berulang-ulang, untuk mempersingkat waktu pembayaran. Apalagi mobilitas dari pejabat-pejabat yang tinggi dapat memperburuk keadaan, karena memerlukan waktu yang lama untuk mencari tanda tangan para pejabat terkait. Perencanaan teknis kegiatan pengadaan gedung kantor di awali dengan pembuatan Detail Engineering Design (DED). Semester awal tahap penyelesaian DED, dilanjutkan dengan persiapan pengadaan, pelaksanaan pengadaan baru dapat dilaksanakan menjelang semester kedua tahun anggaran, sehingga secara otomatis penyelesaian pekerjaan dan realisasi anggarannya menjelang akhir tahun anggaran. Perencanaan anggaran yang baik memperhitungkan kepastian kebutuhan dan anggarannya, sehingga DED dapat dipersiapkan sebelumnya dan proses pengadaan dapat dilakukan awal tahun anggaran. 
Electronic procurement (E-Procurement) merupakan hal yang penting dalam setiap implementasi E-government pada hampir seluruh pemerintahan. Pada tahap awal pengadaan sering ditemukan kendala klasik yang dihadapi oleh panitia/pejabat pengadaan yaitu penerbitan E-catalog. Pelaksanaan pengadaan barang modal akan semakin terlambat manakala setelah penerbitan E-catalog oleh pusat, ternyata barang-barang yang direncanakan pengadaannya tidak tertera dalam E-catalog. Kendala lain yang di hadapi yaitu adanya kenaikan harga barang pada E-catalog, sehingga dana yang dianggarkan pada RKA tidak mencukupi. Kondisi ini menyebabkan proses pengadaan harus menunggu saat anggaran perubahan. Pihak ketiga sebagai rekanan dalam kegiatan pengadaan juga memicu terjadinya keterlambatan realisasi anggaran pada semester pertama. Kondisi tersebut disebabkan oleh keengganan dari rekanan untuk melakukan amprah pembayaran uang muka pekerjaan, padahal pelaksanaan pekerjaan sudah mulai dilakukan.

Penumpukan realisasi anggaran di akhir tahun juga dipicu oleh pengadaan barang modal dari dinas lain di luar Sekretariat Daerah yang tidak memiliki anggaran di dinas masing-masing, sehingga pengadaannya dilakukan di Perwat. Apalagi pengadaan tersebut tidak direncanakan di perwat, sehingga pengadaannya dilakukan secara mendadak. Persoalan lain yang muncul dalam kondisi tersebut adalah tidak tersedianya cukup dana di bagian perwat, karena pengadaan tersebut memang tidak direncanakan, mengakibatkan kegiatan yang sudah direncanakan diundur pelaksanaannya menunggu anggaran perubahan. 
Ruang lingkup revisi anggaran terdiri dari perubahan rincian anggaran yang disebabkan penambahan atau pengurangan pagu anggaran termasuk pergeseran rincian anggarannya, perubahan atau pergeseran rincian anggaran dalam hal pagu anggaran tetap, atau ralat karena kesalahan administrasi (Heriyanto. 2012). Namun pada kenyataannya, revisi anggaran dimanfaatkan untuk menutupi kelemahan dalam perencanaan anggaran. Banyak program yang tidak terdeteksi pada saat perencanaan, akhirnya dianggarkan pada saat anggaran perubahan, sehingga banyak kegiatan baru yang muncul pada saat anggaran perubahan. Kondisi tersebut mengakibatkan banyak kegiatan yang realisasinya baru bisa dilakukan pada triwulan ke empat. Karena waktu yang tersedia setelah anggaran perubahan hanya tiga bulan, banyak kegiatan yang pengerjaannya dipercepat. Pada prinsipnya kendala yang dihadapi dalam proses pengadaan, perencanaan kebutuhan, pelaksanaan SOP dan lainnya, bermuara pada proses perencanaan dan penganggaran. Apabila perencanaan dan penganggaran sudah dipersiapkan dengan matang, maka kendala yang dihadapi dalam proses pelaksanaan anggaran dapat di antisipasi sebelumnya.

\section{SIMPULAN DAN SARAN}

Hasil penelitian ini menunjukkan bahwa, walaupun masing-masing informan mengungkapkan noema yang berbeda-beda terhadap fenomena, namun noesisnya menunjukkan yakni bahwa faktor utama yang menjadi penyebab terjadinya fenomena sebaran waktu realisasi anggaran belanja modal yang cenderung terkonsentrasi menjelang akhir tahun anggaran pada Sekretariat Daerah Kabupaten Gianyar adalah perencanaan anggaran. Pola Perencanaan anggaran 
yang selama ini berjalan kurang memadai, mengakibatkan banyak kendala dalam proses realisasinya

Dalam rangka mengatasi fenomena sebaran waktu realisasi anggaran belanja modal yang cenderung terkonsentrasi menjelang akhir tahun anggaran pada Sekretariat Daerah Kabupaten Gianyar, maka dapat disarankan beberapa hal sebagai berikut: Perencanaan kebutuhan belanja modal, triwulan berapa dilaksanakan, dan kepastian akan anggaran hendaknya ditetapkan pada saat perencanaan anggaran, sehingga HPS, DED dan dokumen kelengkapan lainnya dapat disiapkan sebelumnya. Pemerintah Daerah Kabupaten Gianyar diharapkan lebih memperhatikan proses perencanaan anggaran. Proses perencanaan dan penyusunan APBD hendaknya, mengacu pada PP Nomor 58 Tahun 2005 tentang Pengelolaan Keuangan Daerah, sehingga proses realisasi anggaran belanja modal dapat dilakukan dengan baik dan terprogram. Untuk meminimalisasi revisi anggaran pada saat anggaran perubahan, maka instansi harus membuat perencanaan anggaran lebih realistis dan sesuai dengan kebutuhan yang ada. Jumlah amprah Uang Persediaan (UP) hendaknya disesuaikan dengan program realisasi yang akan dilakukan pertriwulannya, sehingga anggaran kas tidak mengalami penumpukan pada saldo anggaran kas daerah. Untuk memperlancar proses pengadaan barang/jasa, Harga Perkiraan Sendiri (HPS), Detail Engineering Design (DED) dan spesifikasi barang dapat disiapkan terlebih dahulu, sambil menunggu penerbitan E-catalog dari pusat. Komitmen atasan untuk melaksanakan program pengadaan yang telah direncanakan sangat dibutuhkan, untuk meminimalisir pengadaan dari instansi lain yang bukan menjadi kewenangannya. 


\section{REFERENSI}

Arif E, Halim A. 2011. Identifikasi Faktor-Faktor Penyebab Minimnya Penyerapan Anggaran Pendapatan dan Belanja Daerah (APBD) Kabupaten/Kota di Provinsi Riau Tahun 2011. Simposium Nasional Akuntansi XVI.

Argyris C. 1953. Human Problems with Budgets. Harvard Business Review. 31(1). 97-110.

Asih I D. 2005. Fenomenologi Husserl: Sebuah Cara Kembali ke Fenomena. (tesis). Universitas Indonesia.

Conia, Nelson. 2004. Fiscal Planing, Budgeting, and Rebudgeting Using Revenue Semaphores. Public Administration Review. 64. 164-179.

Conyers, Diana, Hills. 1984. An introduction to development planning in the third word. New York: Wiley and Sons.

Darwanto, Yustikasari Y. 2007. Pengaruh Pertumbuhan Ekonomi, Pendapatan Asli Daerah, dan Dana Alokasi Umum Terhadap Pengalokasian Anggaran Belanja Modal. Simposium Nasional Akuntansi IV.

Deng S, Peng J. 2011. Reforming the Budgeting Process in China. OECD Journal on Budgeting. 2011(1). 75-89.

Engkus K. 2009. Metodelogi Penelitian Komunikasi, Fenomenologi, Konsepsi, Pedoman dan Contoh Penelitian. Bandung: Widya Padjadjaran.

Furchan A. 1992. Pengantar Metode Penelitian Kualitatif. Surabaya: Usaha Nasional.

Gill, M. 2014. The Possibilities of Phenomenology for Organizational Research. Organizational Research Methods. Opus: University of Bath Online Publication Store. 17 (2). 118-137.

Hardiansyah A. 2013. Teori Pengetahuan Edmund Husserl. Jurnal Substantia.15(2). 234.

Herriyanto H. 2012. Faktor-Faktor yang Mempengaruhi Keterlambatan Penyerapan Anggaran Belanja pada Satuan Kerja Kementerian/Lembaga di Wilayah Jakarta. (tesis). Jakarta: Universitas Indonesia. 
Husserl E. 1983. Ideas Pertaining To A Pure Phenomenology And To A Phenomenological Philosophy. Boston: Kluwer academic publishers group.

Javier E. 2012. The Many Senses of Imagination and the Manifestation of Fiction: A View from Husserl's Phenomenology of Phantasy. Husserl Study. 29. 143-162.

Letiche H. 2006. Relationality and Phenomenological Organizational Studies. Tamara Journal. 5. 7.

Miliasih R. 2012. Analisis Keterlambatan Penyerapan Anggaran Belanja Satuan KerjaKementerian/Lembaga TA 2010 di Wilayah Pembayaran KPPN Pekanbaru (tesis). Universitas Indonesia.

Muchsin M, Noor A S. 2011. Misteri Penyerapan Anggaran. Paris Revew. 5-17.

Ogujiuba K. 2014. Capital Budget Implementation in Nigeria: Evidence from the 2012 Capital Budget. Contemporary Economic. 8. 299-314.

Sanders P. 1982. Phenomenology: A New Way of Viewing Organizational Research. Academy of Management Revew. Vol. 3. 353-360.

Siswanto, Dwi A, Rahayu S L. 2010. Faktor-Faktor Penyebab RendahnyaPenyerapan Belanja Kementerian/Lembaga TA 2010. Policy Paper Pusat Kebijakan APBN.

Smith D W. Ronald M. 1982. Husserl and Intentionality: A Study of Mind, Meaning, and language. Dordrecth and Boston: D. Reidel Publishing Co. III. 93-104.

Sukadi. 2012. Analisis Faktor-Faktor yang Mempengaruhi Penumpukan Penyerapan Anggaran Belanja di Akhir Tahun Anggaran (tesis). Yogyakarta. Universitas Gajah Mada

Tamasoleng A. 2015. Analisis Efektivitas Pengelolaan Anggaran Di Kabupaten Kepulauan Siau Tagulandang Biaro. Jurnal Riset Bisnis dan Manajemen 3 (1). $97-110$

Wildavsky A. 2004. The New Politics of Budgetary Process. New York: 5 Edition, Addison Wesley.

Williams M. 2004. Government Cash Management Good and Bad-Practice, http:/treasury.worldbank.org/web/pdf/Williams_technote.pdf. 